
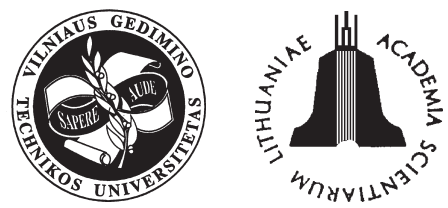

ISSN 1648-4142 TRANSPORT

http:/www.vtu.lt/english/editions

\title{
COMPARATIVE ANALYSIS OF THE DEFINITIONS OF LOGISTICS CENTRES
}

\author{
Ieva Meidutė \\ Dept of Transport Management, Vilnius Gediminas Technical University, \\ Sauletekio al. 11, LT-10223 Vilnius-40, Lithuania.E-mail: jevame@ti.vtu.lt
}

Received 2005-01-05; accepted 2005-03-25

\begin{abstract}
A logistics centre is a center for all the companies which participate in activities related to transport and logistics in the broadest meaning. LCs provide collective equipment needed to develop these activities and have common services for the companies installed there. Together with the values of location and centrality a logistics centre provides quality service and effective selection of the most efficient means of transportation due to its truly multi-modal transport possibilities.
\end{abstract}

Keywords: Logistics centre, evaluation, intermodal transport, multi-modal transport

\section{Introduction}

Logistics centres are a comparatively new phenomenon the birth of which was stimulated by such tendencies as the globalisation of business processes, world technology, intercollaboration and the search for new business solutions.

This phenomenon has not yet received an agreed name. A logistics centre is commonly referred to as a distribution or distribution-storage centre, cargo terminal or central depot, depot base, etc.

The main terms for logistics centres known in Europe can be arranged by countries, e. g.:

- in Great Britain logistics centres are called "Freight Villages",

- in France - "Plate Forme Logistique" or "Plat Forme Multimodales",

- in Germany - "Güterverkehrszentrum",

- in Italy - "Interporto",

- in Denmark - "Transport Centre".

The most common and widely used term in Japan, Singapore, China and the USA is 'logistics centre'. Therefore, there is no unanimous opinion on a single term. However, with the growth of popularity of logistics centres and the profit they make it is likely that the term "logistics centre" will be the most appropriate one.

The term 'logistics centre' is composed out of the compound of two words. In order to perceive the core of this compound this article analyses the concept and origin of these two words separately as well as the origin of the compound itself. In other words, this research concentrates on approaches to logistics centres which are very different depending upon the country where they were built, as well as their purpose. Different authors define and perceive the purpose of logistics centres differently.

\section{Concepts of logistics}

One of the first definitions of logistics is: logistics is a science about the efficient movement of material flows. However, other authors such as D. J. Bowersox extended this proposition stating that logistics guarantees logical and secure succession of storage and streams of supplies, starting from the initial raw material source, going through the manufacturing complex and supply channel and ending with the final consumer [1]. J. M. Masters augmented this concept with the introduction of information and control elements. He stated that logistics is the entirety of an activity dealing with a raw material movement, including information and control systems and embracing all the traditional functions which start with raw material supply and end with the delivery of a final product to the destination [2]. The classical concept of logistics in Scandinavia is considered to be interplay of modelling, organization, coordination, management and control activities, including the movement of material streams, which start from the source of raw material and go through the manufacturing complex, ending with the end consumer [3, 4]. R. Palsaitis suggested the following definition of logistics. According to him logistics is the control of resource flows in the chain of supply as well as the management of the transportation and storage areas and all the fields related to 
them between manufacture and consumption [5-7].

\section{The concept of a centre}

These definitions are given by the Webster's New World dictionary [8]:

- Centre - an intersection point of lines, vectors, forces.

- Centre - the middle, the most important part.

- Centre - the place where something is concentrated, the most important point.

- Centre - the point around which anything revolves.

- Centre - a place at which an activity or complex of activities is carried on.

- Centre - a place from which ideas, influences, etc. emanates.

- Centre - a place to which many people are attracted.

- Centre - the approximate middle point, place or part of anything.

- Centre - a control or management body.

Several definitions of 'nodes' were also given in the dictionary; they state that a node is a point of concentration as well as a central point.

Chambers Science and Technology dictionary gives the following definition of a centre: the point through which all diameters pass [9].

The concept of a centre provided in dictionaries is a diverse one. Therefore, the explanation of its separate meanings is very complicated and confusing; though the primary point of a centre is that it is an object in which a certain activity is concentrated.

\section{The concepts of logistics centres}

After the presenting the separate elements of the 'logistics centre' concept, i. e. 'Logistics' and 'Centre', the interpretations can be analysed applying a common concept of logistics centre (Fig 1).

Attention should be paid to the fact that there is a twofold approach to the concept of Logistics centre; some of the authors in their scientific works tend to think that a logistics centre is a generator of business; others relate it to the transportation infrastructure.

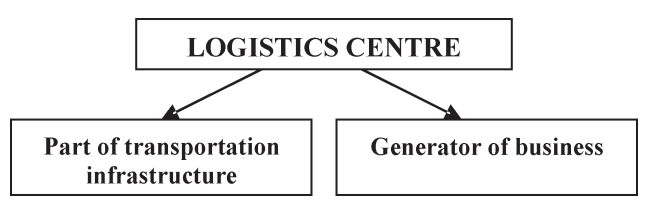

Fig 1. An approach to the concept of Logistics centre

\subsection{A logistics centre as a part of the transpor- tation infrastructure}

Tsamboulas, D. A. in his work referred to a logistics centre as an "integrator" of various transport modes, able to promote intermodal transport". He also identified logistics centres with "an intermodal terminal, which is the principal component of the intermodal transport chain, constituting the node where the transshipment of goods from one mode to the other takes place" [10-11].

Konings, J. W. agreed with this idea. He stressed that the organisation of logistics centres is "interrelated to the intermodal transport chain structure, and especially to the types of markets served, as well as the transport modes and respective volumes". In his work this author emphasised that a logistics centre is"a part of an integrated transport chain that the shipper (customer of the Freight village) develops and operates and as such it comprises terminals and rail/ barge/maritime transport segments as well as the initial and final segments done in most (if not all) cases by road transport" [12].

EUROPLATFORM (European Association of Freight Villages), i.e. the European Association of Freight Villages defined a logistics centre as "an area within which all activities relating to transport, logistics and the distribution of goods, both for national and international transit, are carried out by various operators".

Bretzmann, K. H. and Wenske, Ch. described a Logistics centre "as a freight village being a specific group of transport and warehousing centres "[13].

Krzyzanowski, M. suggested the following definition of a logistics centre: a logistics centre "is representing the multimodal terminals, operates significant cargo streams giving access for a wide variety of transport units, servicing regional, domestic and international markets" [14, 15]. The author distinguished these main functions of a logistics centre: "transport, handling, storage, sorting, labelling etc".

Prokofveja, A. T. states that a Logistics centre is the main systematic element of regional and international macrologistic systems joining the whole movement of cargo streams by a logistics chain, starting with the cargo shipper and ending with the delivery recipient. Also, the author perceived it as a contact point of different transportation types where the distribution of cargo streams is concentrated and performed [16].

Apatjev, I. V. identified a logistics centre as a multifunctional terminal, the main work of which is related to the provision of storage and transportationexpeditionary services grounded by united organisational-economic, financial, informational and juridical supply [17]. 
There are other opinions as well, e. g. Sergejev, V. I. did not provide any definition of logistics centres, but indicated one of the possible objectives of the establishment of a logistics centre. He neither stated that a logistics centre is an element of the transportation infrastructure, nor denied this statement. So, the objective of a logistics centre as formulated by Sergejev is to form an effective monitoring, analytical and managemental system [18] for regional transportational-logistical market services which would secure necessary transportation-expeditionary and cargo storage and distribution services for the customer and answer the world standards both on a manufacture-technological and complex logistical service level.

Table 1. Integral ideas supporting the viewpoint that a logistics centre is a part of the transportation infrastructure, brief definitions according to authors:

Tsamboulas, D.A.

Logistics centre - an integrator of various transportation types, stimulating intermodal transportation

\begin{tabular}{l} 
Konings, J.W. \\
\hline Logistics centre - an element of the intermodal trans- \\
portation chain \\
European Association of Freight Village \\
Logistics centre - a territory where activities related \\
to transportation, logistics and product distribution \\
concentrate
\end{tabular}

Krzyzanowski, M.

Logistics centre - a multimodal terminal, the activity of which deals with cargo transportation, processing, sorting, storage, etc.

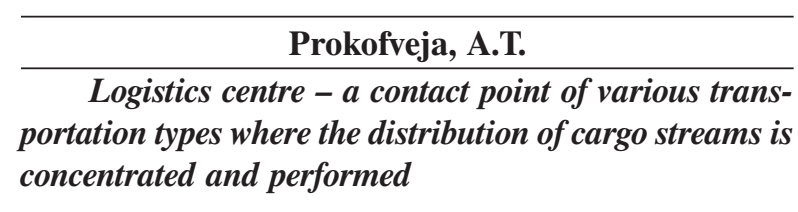

\section{Apatjev, I.V.}

Logistics centre - a multifunctional terminal, the main work of which is a provision of cargo storage and transportational-expeditionary services

Sakalys, A. in his work stated that logistics centres have to correspond to the concept of an open intermodal centre. Moreover, he distinguished the main evaluation factors and criteria of modern logistics centres, which influence the efficiency of them [19].

All the authors analysed emphasised in their works that a logistics centre is a part of the transportation infrastructure which is designed to develop a transportation activity (Table 1). As it was mentioned above, this is not the only viewpoint on the purpose of a logistics centre, it can also be interpreted as a generator of business.

\subsection{A Logistics centre as a generator of busi-} ness

During the analysis of definitions of logistics centres the tendency was noticed that in Japan, Singapore, China and the USA as well as in some European countries logistics centres are interpreted not only as a part of the transportation infrastructure, but also as generators of business. During the research it was noticed that in the activity of certain logistics centres transportation services are not emphasised as the main sphere of the logistics centre activity, but they are perceived as a measure to create and secure beneficial business conditions (Table 2).

Table 2. Integral ideas supporting the viewpoint that a logistics centre is a generator of business, brief definitions according to the authors:

\begin{tabular}{c} 
Goldfogel, J. \\
\hline Logistics centre - an impulse for the development of \\
business and search for new solutions
\end{tabular}
cen for new solions

Manhattan association

Logistics centre - one of the means for successful development of integrated logistics services

Mizushima Port International Logistics Center Co. Ltd

Purpose of the Logistics centre - to stimulate international trade and economic growth in that region

Palsaitis, R.

Logistics centre - a place of logistics services provision or logistics activities concentration place, through which large companies realize business service tasks of their customers

J. Goldfogel, the president of one of the largest and oldest US logistics companies ACME DISTRIBUTION, which started its activity in 1947, defined a logistics centre as a measure which provides an impulse for business and its further development, since not all companies are able in a short period of time to obtain and master the newest technologies, e. g. software programmes for the control of depots, cargo arrangement, sorting, accounting, etc. According to J. Goldfogel, logistics centres can guarantee this for customers (consumers of services of logistics centres), since the idea of logistics centres is to guarantee beneficial and competitive conditions for the companies belonging to it. 
Manhattan Association, which is well known in the US, unifies 16 companies which provide logistics services in 11 countries. They defined a logistics centre as a centre which grants an opportunity to stimulate integrated logistics services. Ongoing business globalisation, the appearance of unexpected consumer needs and inconsistencies in the transportation market (increase/decline of the demand of transportation services) enable integrated logistics services provided in the logistics centre, to secure business continuity and provide an opportunity to optimize the supply system according to needs and stimulate a competitive advantage.

It is not only in the US that logistics centres are defined as measures to stimulate business. The viewpoint in Japan is similar. One of the examples is Mizushima Port International Logistics Center Co. Ltd., the purpose of which is to stimulate international business as well as economic growth in that region.

Analysing the Taiwanese National Development Plan "Challenging 2008" [20], attention was paid to the fact that logistics centres are built on the territory where not only national companies develop their activities, but foreign companies as well, such as those of Holland, Germany, Japan and the USA. For this reason logistics centres of Taiwan are usually equated to the activity of multinational companies, since the local market appears to be of a low economic level, whereas in the logistics centre companies of the economically strongest countries are concentrated. The participation of these companies enlarges the competitive ability of Taiwanese logistics centres and enables their integration into global chains of supply.

Palsaitis, R. states that logistics centres from a business point of view are well-studied solutions which allow the reduction of the number of depots in the city, country/region, as well as provide transportation services closer to manufacturing centres and supermarkets $[5,21]$.

Other examples exist as well, which prove that logistics centres generate business. Perennial experience of the activity of logistics centres shows that Logistics centres not only secure the development of business, but also have an economic effect on the region where they are established. This is proven by the spectrum of services provided in logistics centres (Fig 2).

The economic effect can be manifested differently, e. g. by the increase in cargo streams, business stimulation, the creation of new work places, etc.

For the implementation of the provision of the services above buildings with specific purposes have to be built within the territory of a logistics centre (Fig 3).

In summary it can be said that supporters of both viewpoints are partly right since a logistics centre combines a lot of different types of activity and secures an efficient business function.

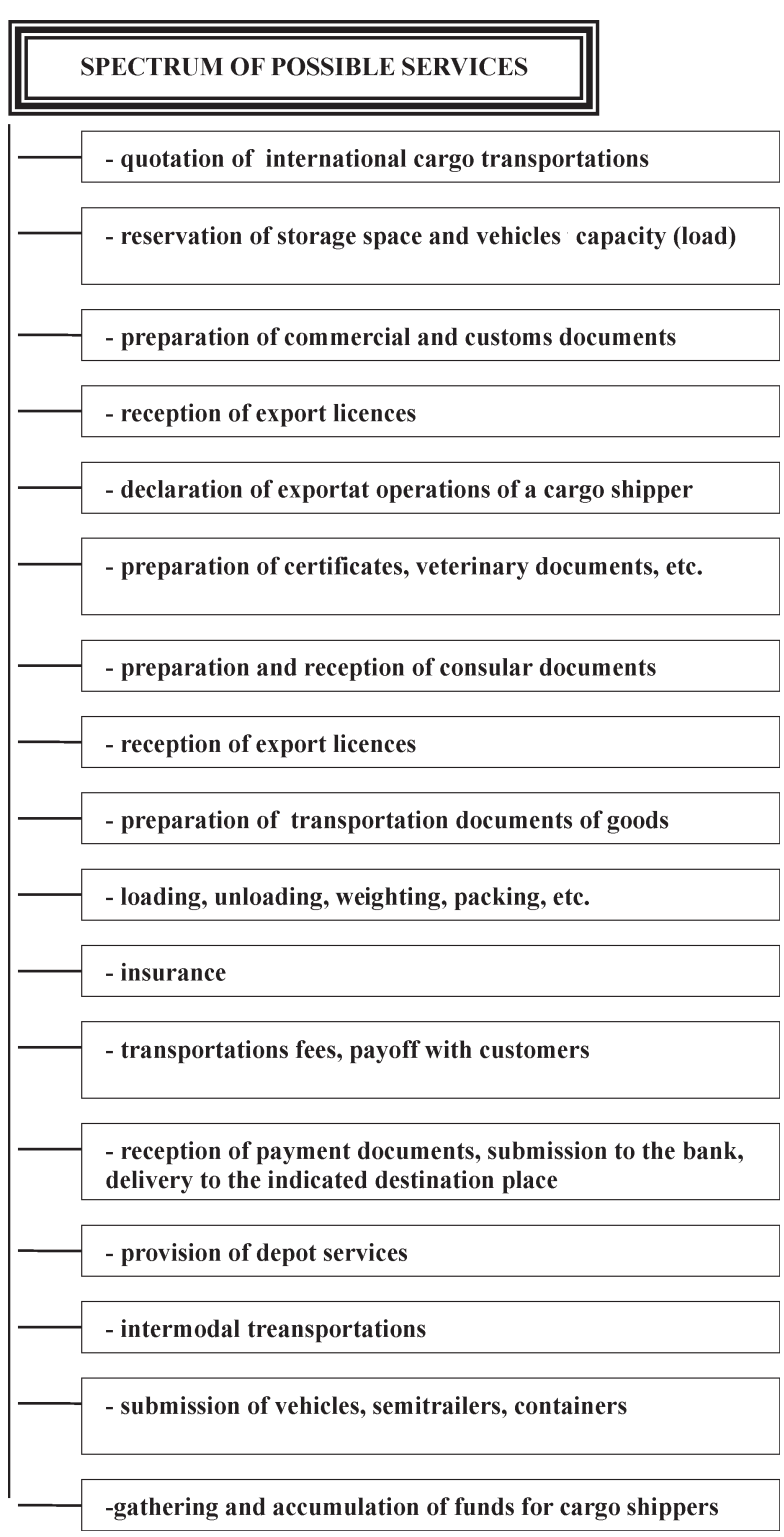

Fig 2. Spectrum of services provided in logistics centres

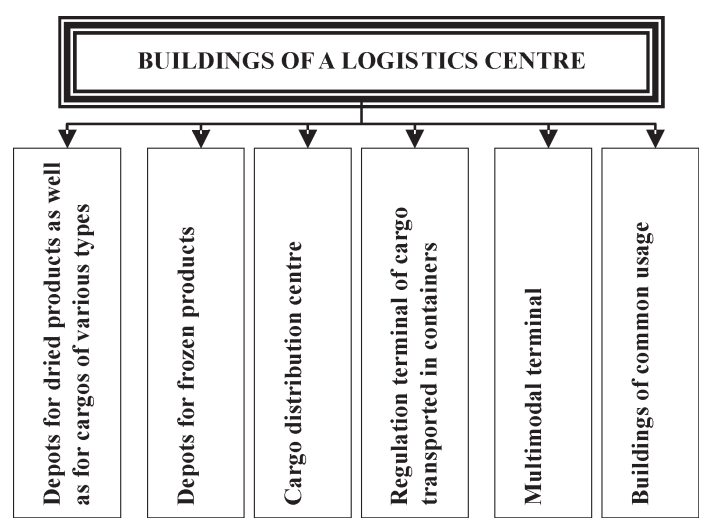

Fig 3. Buildings of a logistics centre 


\section{Conclusions}

1. The appearance of logistics centres was stimulated by the globalisation of business processes, the search for new business solutions and intercollaboration possibilities.

2.After analysing logistics centres it appeared that there is no clear viewpoint on a single definition of the 'Logistics centre'.

3. The results of the analysis show that two viewpoints occur, i.e. logistics centre as a part of the transportation infrastructure (this statement is more favoured in Europe and Central Asia) and a logistics centre as a generator of business (this statement is favoured by the US and Asian scientists as well as business representatives).

4. Summing-up, it can be said that the decision to establish a logistics centre should keep in mind many factors, such as the right location, a current infrastructure level in the region, beneficial and competitive conditions for business securing business development and the economic effect in the region.

\section{References}

1. Bowersox, D. J. Logistical Management: A Systems Integration of Physical Distribution Management, Material Management, and Logistical Co-ordination. New York: MacMillan Publishing Co., Inc., 1974. 516 p.

2. Masters, J. M.; Pohlen, T. L. Evaluation of the Logistics Proffesion. In: The Logistics Hadbook (edited by J. F. Robeson \&W. C. Copacino). New York: The Free Press, 1994, p. 13-34.

3. Johaneessen, S.; Solem, O. Logistic organizations: Ideologies, Principles and Practice. The International Journal of Logistics Management, Vol 13, No 1, 2002, p. 8 16.

4. Solem, O. Logistic organizations: Ideologies, Principles and Practice. In: Logistics from epistemological point of view. Seminar. School of Business, National University of Singapore. 2003, p. 1-68.

5. Bazaras, D; Palšaitis, R. Analysis of the Perspectives of Intermodal Transport and logistics centres in Lithuania. Transport, Vol XIX, No 3, Vilnius: Technika, 2004, p. 119-123.

6. Palšaitis, R. Logistics centers and transit transport interfaces in Lithuania. In: Sientific proceedings of Riga Technical University, Economics and Business. Business and Management. Riga, 2004, p. 83-88.

7. Palšaitis, R. Logistics Centers Influence to the Economical Development of the Region. In: Conference Proceedings. Development of Logistics, Transport and Communication Services in the Baltic Sea Region. International Conference. Vilnius, 2004, p. 21-26.

8. Webster's New World Dictionary of American English. Third College Edition, 1988. 1574 p.
9. Chambers Sience and Technology dictionary, 1988. 1008 p.

10. Tsamboulas, D. and Dimitropoulos, J. Appraisal of investments in European nodal centres for goods: a comparative analysis. Transportation, Vol 33, 1999, p. 141156.

11. Tsamboulas, D. and Kapros, S. Freight village evaluation under uncertainty with public and private financing. Transport Policy, Vol 10, No 2, 2003, p. 141-156.

12. Konings, J. W. Integrated Centres for the Transshipment, Storage, Collection, Distribution of Goods. Transport Policy, Vol III, No 1/2, 1994, p. 3-11.

13. Breitzmann, K. H.; Wenske, Ch. NeLoc: Planing of Logistics Centres. Final report. Gdansk, 2003, p. 12.

14. Krzyzanowski, M. The Logistics Centres Adapted to the Demands of the Developing Countries (West and Middle European Case). In: Bulletin of the Maritime Institute. Gdansk, 1999, p. 15-28.

15. Krzyzanowski, M. Logistics Centres in Poland, with Special Attention Given to the Pomerskie Voivodship. In: Bulletin of the Maritime Institute. Gdansk, 2000, p. 2531.

16. Prokofjeva, A. T.; Lopatkin, O. M. The Logistics of transport-distribution system: regional aspect (Логистика транспортно-распределительных систем: региональный аспект). Moscow, 2003. 400 p. (in Russian).

17. Apatjev, I. B.; Levin, C. B. The Logistical Systems of Transport (Логистические транспортно-грузовые системы). Moscow, 2003. 304 p. (in Russian).

18. Sergejev, V. I.; Kizin, A. A. The Global Logistics Systems (Глобальные логистические системы) Sankt-Peterburg, 2001. 240 p. (in Russian).

19. Šakalys, A.; Balčiauskienè, S. Formation of New Generation Logistics Centres in Lithuania. In: 4-th International Conference. Vilnius, 2003, p. 41-50.

20. Taiwan's national Development Plan "Challenging 2008". Part; The Globe Logistics Development plan. 2003, p. 1-9.

21. Palšaitis, R.; Paliulis, N. Management of Logistics (Logistikos vadyba). Vilnius: Verslo žinios, 2003-2004, 620 p. (in Lithuanian). 